\section{Media Publikasi Promosi Kesehatan Indonesia The Indonesian Journal of Health Promotion}

\title{
Hubungan Karakteristik Demografik Dengan Niat Melakukan Hubungan Seksual Pranikah Pada Remaja Laki-Laki Indonesia
}

\author{
Association Between Demographic Characteristics Towards Sexual Intention On \\ Unmarried Young Men In Indonesia
}

\author{
${ }^{\left(1^{*}\right)}$ Mohammad Ainul Maruf , ${ }^{(2)}$ Kerry Richter, ${ }^{(3)}$ Amara Soonthorndada \\ ${ }^{\left({ }^{*}\right)}$ Fakultas Kesehatan Masyarakat, Universitas Muhammadiyah Jakarta \\ ${ }^{(2-3)}$ Insitute for Population and Social Research, Mahidol University \\ (*)arvin.ainul@hotmail.com \\ (") Corresponding Author
}

\begin{abstract}
Abstrak
Persentase laki-laki muda yang belum menikah memiliki pengalaman seksual meningkat dari $6 \%$ pada tahun 2007 menjadi $8 \%$ pada tahun 2012. Perilaku seks sebelum menikah lebih diterima diantara laki-laki muda sementara itu pendidikan seksual yang komprehensif belum diterapkan secara menyeluruh dalam kurikulum pendidikan nasional dan belum merata di semua daerah. Hal ini menghalangi anak muda untuk mendapatkan informasi yang benar. Penelitian ini menguji hubungan antara karakteristik demografik dengan niat untuk melakukan hubungan seksual pranikah pada remaja laki-laki usia 15 hingga 24 tahun di Indonesia. Data didapatkan dari Survei Demografi dan Kesehatan Indonesia tahun 2012. Sebanyak 9,109 responden terpilih untuk dianalisis. Analisis data terdiri dari analisis deskriptif dan analisis bivariat dengan menggunakan uji chi-square. Hasil penelitian menunjukkan ada sekitar $21.1 \%$ remaja laki-laki yang mengungkapkan bahwa mereka berniat untuk melakukan hubungan seksual sebelum menikah. Niat tersebut ditemukan lebih umum diantara mereka yang berusia 20-24 tahun. Hasil uji bivariat menunjukkan bahwa ada hubungan antara kelompok usia, tingkat pendidikan, daerah tempat tinggal sebagai proxy dari agama dan status tempat tinggal dengan niat melakukan hubungan seksual. Temuan ini menyarankan perlunya pendekatan yang beragam dalam penerapan pendidikan seksualitas pada remaja.
\end{abstract}

Kata Kunci : Karakteristik; predisposisi; niat; seksual

\begin{abstract}
The percentage of unmarried young men having sexual experience increased from 6\% in 2007 to $8 \%$ in 2012. Pre-marital sexual behavior is more acceptable among young men while comprehensive sexual education has not been applied thoroughly in the national education curriculum and not evenly distributed in all regions. This prevents young people from getting the right information. This study examines the relationship between demographic characteristics and the intention to have premarital sexual relations among male adolescents aged 15 to 24 years in Indonesia. Data was obtained from the 2012 Indonesia Demographic and Health Survey. 9,109 respondents were selected for analysis. Data analysis consisted of descriptive analysis and bivariate analysis using the chi-square test. The results showed that there were about $21.1 \%$ of teenage boys who revealed that they intended to have sexual relations before marriage. This intention was found to be more common among those aged 20-24 years. The results of the bivariate test show that there is a relationship between age groups, education level, area of residence as a proxy of religion and residence status with the intention of having sexual relations. These findings suggest the need for a diverse approach in the application of sexuality education to adolescents.
\end{abstract}

Keywords: Characteristics; predisposition; intention; sexual 


\section{PENDAHULUAN}

Para peneliti menaruh perhatian terhadap penyebab remaja di Indonesia melakukan hubungan seksual dan perilaku berisiko lainnya pada usia yang relatif muda (1). Penelitian-penelitian tersebut mendorong pendidik, pembuat kebijakan dan penyedia layanan kesehatan untuk membuat dan mengembangkan lebih banyak intervensi efektif yang dapat memberikan dampak positif bagi generasi masa depan (2).

Indonesia menempati urutan keempat negara dengan jumlah penduduk terbanyak sebanyak 237 juta jiwa, dimana seperempatnya adalah anak muda usia 10-24 tahun (3). Remaja Indonesia mengalami perubahan sosial, budaya dan demografik yang sangat cepat (4). Mereka lebih terpapar dengan pendidikan, media massa, internet dan program pemerintah, terutama yang hidup di daerah perkotaan. Selain itu, mereka juga lebih bebas dalam menyikapi perubahan nilai seperti yang dialami remaja-remaja di Dunia Barat, termasuk dalam isu seksualitas (5).

Data Survei Demografi dan Kesehatan Indonesia (SDKI) menunjukkan adanya peningkatan presentase remaja yang melakukan hubungan seksual sebelum menikah, terutama remaja laki-laki. Pada tahun 2007, terdapat 6\% responden remaja laki-laki yang mengaku telah melakukan hubungan seksual. Persentase tersebut meningkat menjadi 8\% responden pada tahun 2012.(6,7) Meskipun begitu, pendidikan seksual belum diimplementasikan dalam kurikulum pendidikan nasional sehingga menghambat mereka mendapatkan informasi yang benar (4). Menurut UU Kesehatan, pendidikan kesehatan reproduksi merupakan bagian dari kesehatan remaja yang harus diberikan kepada setiap anak dan remaja usia sekolah (8).

Anak muda tidak berbicara secara terbuka mengenai seksualitas dengan orang tua dan guru mereka. Orang tua jarang memberikan informasi mengenai seksualitas dan guru masih memegang teguh norma konservatif (4). Pemberian informasi mengenai pendidikan seksual juga terancam dikriminalisasi oleh aturan yang melarang pornografi (9). Pemerintah Indonesia masih melihat isu ini sebagai sesuatu yang kontroversial dan sensitif, sehingga pendekatan yang digunakan adalah berbasis moral bukan pendekatan berbasis kesehatan dan hak asasi (10).

Stigma sosial dari masyarakat umum terhadap anak muda juga masih menjadi masalah. Anak laki-laki dianggap lebih rentan terhadap perilaku berisiko dan berbahaya (5). Dalam masyarakat yang Islami, idealnya hubungan antara laki-laki dan perempuan dibatasi dan peran kedua jenis kelamin tersebut dibedakan. Laki-laki harus matang secara finansial sebelum mereka menikah, dan perempuan mendapatkan tempat di masyarakat setelah mereka menikah (11). Hubungan seksual pranikah, atau zina, bagi laki-laki dan perempuan dipandang sebagai dosa besar dan harus dihukum dengan hukuman rajam (11).

Tidak seperti pada perempuan, hubungan seksual pranikah lebih diterima pada laki-laki dan laki-laki lebih mudah melaporkan dirinya telah melakukan hubungan seksual pranikah (12). Laki-laki meyakini perlunya memiliki pengalaman seksual sebelum menikah (13). Meskipun mereka menyadari bahaya penyakit menular seksual, kebanyakan dari mereka tidak merasa butuh menggunakan kondom (4).

Penelitian ini berfokus pada remaja laki-laki dan bukan pada remaja perempuan dengan alasan: 1) adanya peningkatan persentase melakukan hubungan seksual pranikah pada remaja laki-laki, dan 2) diasumsikan bahwa penelitian pada remaja laki-laki juga akan memberikan keuntungan pada remaja perempuan. Temuan penelitian ini diharapkan akan menghasilkan masukan bagi pemerintah untuk mengembangkan kebijakan dan program yang dapat mendorong remaja laki-laki menunda untuk melakukan hubungan seksual dan menghindari perilaku seksual tidak aman. 


\section{METODE}

Jenis penelitian ini merupakan penelitian analitik dengan rancangan cross sectional. Sumber data penelitian berasal dari data sekunder, Survei Demografi dan Kesehatan Indonesia 2012, terutama dari kuesioner remaja lakilaki usia 15 hingga 24 tahun. Data dikumpulkan oleh Badan Pusat Statistik (BPS) dan Kementerian Kesehatan RI dari tanggal 7 Mei sampai 31 Juli 2012. Sampel dipilih secara random menggunakan teknik pengambilan sampel stratified multi-stage. Jumlah sampel penelitian sebanyak 9.109 responden. Analisis dilakukan dengan menggunakan analisis univariat dan analisis bivariat. Variabel dependen dari penelitian ini adalah niat melakukan hubungan seksual, sementara itu variabel independennya adalah karakteristik demografi yang meliputi usia, tingkat pendidikan, daerah tempat tinggal sebagai proxy dari agama mayoritas dan status tempat tinggal apakah di daerah perkotaan atau pedesaan. Penelitian ini mendapatkan surat persetujuan etik dari Institute for Population and Social Research (IPSR) - Institutional Review Board, Mahidol University dengan kode referensi COA. No.2016/07-060. Dikarenakan survei dilaksanakan diantara kelompok anak muda, maka persetujuan dari orang tua/wali diminta sebelum proses wawancara dilakukan, terutama pada responden di bawah usia 18 tahun. Lembar persetujuan menanyakan apakah orang tua/wali setuju anak mereka diwawancarai secara pribadi. Persetujuan setelah penjelasan (PSP) menjamin informasi yang diberikan oleh responden akan dijaga kerahasiaannya dan responden diperkenankan untuk tidak menjawab pertanyaan tertentu.

\section{HASIL}

Berdasarkan hasil analisis univariat, didapatkan data distribusi responden berdasarkan kelompok usia, tingkat pendidikan, daerah tempat tinggal dan pendidikan serta status tempat tinggal. Tabel 1 menunjukkan bahwa mayoritas subjek dalam penelitian ini berada pada kelompok usia 15-19 tahun.

Tabel 1.

Distribusi Frekuensi Responden berdasarkan Kelompok Usia

\begin{tabular}{ccc}
\hline Usia (tahun) & Frekuensi & Persentase \\
\hline $15-19$ & 5.894 & 64,7 \\
$20-24$ & 3.215 & 35,3 \\
Total & 9.109 & 100 \\
\hline
\end{tabular}

Tabel 2 menunjukkan bahwa lebih dari setengah jumlah responden mengenyam pendidikan terakhir pada tingkat sekunder atau sekolah menengah. Sepertiga jumlah responden mengenyam pendidikan pada perguruan tinggi dan sisanya mengenyam pendidikan dasar sebagai pendidikan terakhir yang ditempuh.

Tabel 2.

Distribusi Frekuensi Responden berdasarkan Tingkat Pendidikan

\begin{tabular}{ccc}
\hline Pendidikan & Frekuensi & Persentase \\
\hline SD & 1.257 & 13,8 \\
SMP-SMA & 4.764 & 52,3 \\
Perguruan Tinggi & 3.088 & 33,9 \\
Total & 9.109 & 100 \\
\hline
\end{tabular}

Daerah tempat tinggal digunakan sebagai proxy bagi agama dominan, dengan berlandaskan data Sensus Penduduk 2010. Daerah mayoritas Muslim adalah kepulauan Sumateran, kepulauan Jawa, Nusa Tenggara Barat, Kepulauan Kalimantan, Kepulauan Sulawesi dan Maluku Utara. Daerah yang didominasi Muslim dan Kristiani ada- 
lah Sumatera Utara, Kalimantan Barat dan Maluku. Daerah yang hanya didominasi umat Kristiani adalah Nusa Tenggara Timur, Sulawesi Utara dan Kepulauan Papua. Sementara, daerah mayoritas Hindu adalah kepulauan Bali. Tabel 3 menunjukkan bahwa mayoritas responden tinggal di daerah dengan mayoritas agama Islam. Sebanyak 8\% responden tinggal di daerah dengan mayoritas agama Islam dan Kristiani, 3.5\% mayoritas Kristiani dan 1.6\% mayoritas Hindu.

Tabel 3.

Distribusi Frekuensi Responden berdasarkan Daerah Tempat Tinggal

\begin{tabular}{lcc}
\hline \multicolumn{1}{c}{ Daerah Tempat Tinggal } & Frekuensi & Persentase \\
\hline Mayoritas Muslim & 7.915 & 86,9 \\
Muslim dan Kristiani & 729 & 8,0 \\
Mayoritas Kristiani & 319 & 3,5 \\
Mayoritas Hindu & 146 & 1,6 \\
\multicolumn{1}{c}{ Total } & 9.109 & 100 \\
\hline
\end{tabular}

Sejalan dengan semakin besarnya laju urbanisasi di Indonesia, tabel 4 menggambarkan responden yang tinggal di daerah perkotaan lebih banyak daripada mereka yang tinggal di daerah pedesaan.

Tabel 4.

Distribusi Frekuensi Responden berdasarkan Status Tempat Tinggal

\begin{tabular}{ccc}
\hline Pekerjaan & Frekuensi & Persentase \\
\hline Urban & 5.065 & 55,6 \\
Rural & 4.044 & 44,4 \\
Total & 9.109 & 100 \\
\hline
\end{tabular}

Tabel 5 menggambarkan bahwa sebagian besar responden menyatakan belum berniat melakukan hubungan seksual (78.9\%). Hanya seperlima (21.1\%) anak muda laki-laki yang berniat melakukan hubungan seksual segera.

Tabel 5.

Distribusi Frekuensi Responden Berniat Melakukan Hubungan Seksual

\begin{tabular}{ccc}
\hline Pekerjaan & Frekuensi & Persentase \\
\hline Tidak berniat & 7.187 & 78,9 \\
Berniat & 1.922 & 21,1 \\
Total & 9.109 & 100 \\
\hline
\end{tabular}

Tabel 6 menunjukkan hubungan antara kelompok usia, tingkat pendidikan, daerah tempat tinggal sebagai proxy dari agama dan status tempat tinggal. Menurut kelompok usia, berdasarkan uji statistik menggunakan chi square, didapatkan nilai p-value kurang dari 0.01 antara kelompok usia dengan variabel dependen. Dengan demikian, kelompok usia berhubungan secara signifikan dengan niat melakukan hubungan seksual. Semakin tua kelompok usia responden memiliki niat berhubungan seksual yang semakin besar (28,3\% berbanding $17,1 \%)$. Tingkat pendidikan responden juga berhubungan kuat dengan niat berhubungan seksual dengan p-value kurang dari 0.01 . Anak muda laki-laki yang telah mengenyam pendidikan tinggi memiliki niat yang lebih besar untuk melakukan hubungan seksual daripada mereka yang telah mengenyam pendidikan menengah dan pendidikan dasar $(28,9 \%$ berbanding dengan $16,6 \%$ dan $18,7 \%)$. 
Penelitian ini juga menemukan bahwa ada hubungan signifikan antara daerah tempat tinggal responden sebagai proxy dari agama dengan niat melakukan hubungan seksual secara statistik ( $\mathrm{p}$-value $<0.01$ ). Responden yang tinggal di daerah dengan mayoritas penduduk Kristiani mempunyai persentase tertinggi $(41,8 \%)$ berniat melakukan hubungan seksual ketika dibandingkan dengan mereka yang tinggal di daerah lainnya; daerah mayoritas Hindu sebesar 34,2\% dan daerah gabungan mayoritas Muslim dan Kristiani 33.1\%. Pada daerah mayoritas Muslim, persentase berniat melakukan hubungan seksual terkecil yaitu hanya $18,9 \%$. Ada hubungan yang signifikan pula antara status tempat tinggal dengan niat melakukan hubungan seksual (p-value $<0.05$ ). Mereka yang tinggal di daerah perkotaan memiliki persentase yang lebih tinggi ingin melakukan hubungan seksual dibandingkan dengan mereka yang tinggal di pedesaan (22.7\% berbanding 19,0\%).

Tabel 6.

Hubungan Karakteristik Demografik dengan Niat Melakukan Hubungan Seksual

\begin{tabular}{llcccc}
\hline \multirow{2}{*}{ Karakteristik } & \multicolumn{3}{c}{ Niat melakukan hubungan seksual (\%) } \\
\cline { 3 - 5 } & & Tidak berniat & Berniat & Total & Chi-square \\
\hline Kelompok usia & $15-19$ & 82,9 & 17,1 & 100 & $156,7 * * *$ \\
& $20-24$ & 71,7 & 28,3 & 100 & \\
Tingkat & SD & 81,3 & 18,7 & 100 & $176,4 * * *$ \\
Pendidikan & SMP - SMA & 83,4 & 16,6 & 100 & \\
\multirow{2}{*}{ Daerah tempat } & Merguruan Tinggi & 71,1 & 28,9 & 100 & \\
Tinggal & Muslim & 81,1 & 18,9 & 100 & $185,2 * * *$ \\
& Kuslim Kristiani & 66,9 & 33,1 & 100 & \\
\multirow{2}{*}{ Status tempat } & 58,2 & 41,8 & 100 & \\
Tinggal & Hindu & 65,8 & 34,2 & 100 & \multirow{2}{*}{$18,0^{* *}$} \\
\hline
\end{tabular}

$* p<0.10 * * p<0.05 * * * p<0.01$

\section{PEMBAHASAN}

Temuan penelitian menunjukkan bahwa ada hubungan antara karakteristik demografik (faktor predisposisi) dengan niat melakukan hubungan seksual. Mengenai usia, anak muda laki-laki yang lebih dewasa memiliki hasrat berhubungan seksual lebih tinggi daripada mereka yang lebih muda. Temuan ini sejalan dengan penelitian di Hong Kong yang menunjukkan bahwa remaja yang lebih tua lebih mungkin untuk memiliki niat melakukan hubungan seksual daripada yang lebih muda dan sebuah penelitian di Amerika Serikat yang menunjukkan remaja yang lebih tua lebih mungkin untuk memulai hubungan seksual daripada remaja yang lebih muda $(14,15)$.

Tingkat pendidikan diperkirakan sejalan dengan usia. Temuan ini menunjukkan bahwa semakin tinggi tingkat pendidikan remaja laki-laki yang belum menikah semakin besar niat untuk segera melakukan hubungan seksual. Ini menunjukkan bahwa kedua temuan ini (usia dan tingkat pendidikan) konsisten.

Mengenai daerah tempat tinggal yang mewakili agama dominan, remaja laki-laki yang tinggal di wilayah mayoritas Kristiani seperti Nusa Tenggara Timur, Sulawesi Utara dan kepulauan Papua memiliki niat melakukan hubungan seksual paling tinggi. Sebaliknya, mereka yang tinggal di wilayah mayoritas Muslim seperti Kepulauan Sumatera, Kepulauan Jawa, Nusa Tenggara Barat, Kepulauan Kalimantan, Kepulauan Sulawesi dan Maluku Utara 
memiliki niat hubungan seksual paling rendah. Dalam pengajaran Kristen, hukuman bagi mereka yang terlibat dalam seks pranikah kurang menakutkan. Sementara itu, dalam ajaran Islam, seks pranikah jelas dipandang sebagai dosa besar yang akan dihukum 100 kali cambukan (16). Selain itu, pemuda non-Muslim punya keyakinan kurang konservatif dibandingkan dengan pemuda Muslim (17).

Lebih dari separuh remaja laki-laki tinggal di daerah perkotaan. Mereka mempunyai niat yang sedikit lebih tinggi untuk berhubungan seksual daripada mereka yang tinggal di daerah pedesaan. Tradisi, budaya dan agama lebih dipelihara di daerah pedesaan. Sementara itu, daerah perkotaan lebih modern dan karena itu kurang memperhatikan tradisi, budaya dan agama. Di pusat-pusat perkotaan, membahas tentang seksualitas juga lebih terbuka (17).

\section{KESIMPULAN DAN SARAN}

Penelitian ini menguji hubungan antara niat melakukan hubungan seksual dengan faktor-faktor predisposisi terkait di kalangan remaja laki-laki yang belum menikah di Indonesia. Penelitian ini menggunakan data sekunder dari komponen Kesehatan Reproduksi Remaja dari Survei Demografi dan Kesehatan Indonesia tahun 2012 yang berfokus hanya pada data remaja yang belum pernah menikah. Terungkap bahwa seperlima dari responden berniat untuk segera melakukan hubungan seksual. Lebih dari setengah responden berada di kelompok usia 15 hingga 19 tahun. Sebagian besar responden telah menyelesaikan sekolah menengah dan perguruan tinggi. Sebagian besar responden tinggal di wilayah mayoritas Muslim dan lebih dari setengah tinggal di daerah perkotaan.

Karakteristik demografik seperti usia, tingkat pendidikan, wilayah tempat tinggal (sebagai proxy agama dominan) dan status tempat tinggal secara statistik signifikan berhubungan dengan niat hubungan seksual. Penelitian ini menemukan bahwa remaja laki-laki yang belum menikah dengan usia yang lebih dewasa memiliki niat melakukan hubungan seksual yang lebih tinggi daripada mereka yang lebih muda. Niat hubungan seksual secara bertahap meningkat dari remaja laki-laki yang menyelesaikan sekolah dasar diikuti mereka yang telah menyelesaikan sekolah menengah hingga lebih tinggi pada mereka yang telah menyelesaikan perguruan tinggi. Wilayah tempat tinggal yang berbeda memiliki efek pada niat melakukan hubungan seksual. Laki-laki muda yang belum menikah yang tinggal di wilayah mayoritas Kristiani memiliki niat melakukan hubungan seksual yang lebih tinggi daripada mereka yang tinggal di daerah lain. Mereka yang tinggal di daerah perkotaan memiliki niat melakukan hubungan seksual yang sedikit lebih tinggi daripada mereka yang tinggal di daerah pedesaan.

Hasil penelitian ini diharapkan mampu membantu pembuat kebijakan untuk merancang strategi dan progran kesehatan reproduksi remaja yang terkait dengan perilaku atau gaya hidup laki-laki muda di Indonesia. Pendekatan yang berbeda diperlukan berdasarkan tingkat pendidikan, agama yang dianut dan status tempat tinggal. Bagi remaja laki-laki yang masih menempuh pendidikan sekolah menengah dan ke bawah, pendidikan seksual perlu diarahkan untuk mendorong mereka menunda hubungan seksual. Sementara itu, bagi remaja laki-laki yang telah menempuh pendidikan tinggi, pendidikan seksual lebih diarahkan untuk mempromosikan gaya hidup seksual yang sehat dan persiapan menuju kehidupan berumah tangga. Penggunaan media perlu dikembangkan. Internet dapat dimaksimalkan pada daerah perkotaan, sementara media cetak atau tulis dapat lebih dimaksimalkan di daerah pedesaan yang memiliki akses internet terbatas. Pendekatan yang lebih moderat perlu dilakukan agar remaja laki-laki mau berdiskusi lebih terbuka mengenai permasalahan seksualitas mereka kepada orang tua, guru atau dosen, petugas layanan kesehatan dan pemuka agama. Petugas layanan kesehatan diharapkan dapat lebih aktif mengunjungi sekolah ataupun kampus bekerjasama dengan tenaga pengajar dan pendidik untuk memberikan informasi mengenai gaya hidup seksual yang sehat untuk mengimbangi informasi tidak akurat yang didapatkan oleh remaja laki-laki. 


\section{DAFTAR PUSTAKA}

1. Azinar M. Perilaku seksual pranikah berisiko terhadap kehamilan tidak diinginkan. J Kesehat Masy. 2013;8 (2):153-160.

2. Buhi ER, Goodson P. Predictors of adolescent sexual behavior and intention: A theory-guided systematic review. J Adolesc Heal. 2007;40(1):4-21.

3. Badan Pusat Statistik. Sensus Penduduk tahun 2010. http://sp2010/bps.go.id/. Published 2011.

4. Situmorang A. Adolescent Reproductive Health in Indonesia.; 2003. https://pdf.usaid.gov/pdf_docs/ Pnacw743.pdf.

5. Utomo ID. Adolescent reproductive health in Indonesia: Status, policies, programs, and issues. Policy Rep. 2003.

6. Badan Pusat Statistik, Makro Internasional. Survei Demografi Dan Kesehatan Indonesia 2007. Jakarta; 2008. https://dhsprogram.com/pubs/pdf/FR219/FR219.pdf.

7. Kementrian Kesehatan RI. Survei Demografi Dan Kesehatan Indonesia 2012. Jakarta; 2013. https:// dhsprogram.com/pubs/pdf/FR281/FR281.pdf.

8. Undang-Undang No. 36 Tahun 2009 Tentang Kesehatan. Jakarta; 2009.

9. UNICEF Indonesia. Responding to HIV and AIDS.; 2012. https://www.unicef.org/indonesia/A4_E_Issue_Brief_HIV_REV.pdf.

10. Zaman W, Frances M. Improving Access of Young People to Education and Services for Sexual and Reproductive Health, HIV and Gender: Promising Practices in Indonesia, Thailand and Vietnam. Malaysia: International Council on Management of Population Programmes; 2009.

11. Gregg GS. Culture and Identity in a Muslim Society. New York: Oxford University Press; 2007.

12. Blum R, Mmari N. Risk and Protective Factors Affecting Adolescent Reproductive Health in Developing Countries. Geneva; 2005. http://www.who.int/child-adolescent-health/New_Publications/ADH/ ISBN_92_4_159365_2.pdf.

13. Utomo ID, McDonald P. Adolescent reproductive health in Indonesia: Contested values and policy inaction. Stud Fam Plann. 2009;40(2):133-146.

14. Shek DTL, Leung H. Do adolescent sexual behavior and intention to engage in sexual behavior change in high school years in Hong Kong? J Pediatr Adolesc Gynecol. 2016;29(1):S49-S60.

15. Kinsman SB, Romer D, Furstenberg FF, Schwarz DF. Early sexual initiation: the role of peer norms. Pediatrics. 1998;102(5):1185-1192.

16. Khalifa R. Quran - the Final Testament: Authorized English Version of the Originial. California: Universal Unity; 2010.

17. Holzner BM, Oetomo D. Youth, sexuality and sex education messages in Indonesia: Issues of desire and control. Reprod Health Matters. 2004;12(23):40-49. 